\title{
How Best to Link Poverty Reduction and Debt Sustainability in IMF-World Bank Models?
}

\author{
BRIGITTE GRANVILLE* \& SUSHANTA MALLICK** \\ *Centre for Business Management, Queen Mary, University of London, UK; **Department of \\ Economics, Loughborough University, UK
}

\begin{abstract}
This paper attempts to provide an economic model in the context of developing countries to address the policy strategies related to poverty reduction. With a view to deal with the shortcomings of the existing approaches as regards poverty reduction, this paper develops a model on the basis of the policy framework of the IMF and the World Bank to show how demand growth can be a crucial mechanism in determining the potential rate of growth, and then to suggest ways in which poverty-conceptualised officially in absolute terms with a subjective cut-off point (e.g. US \$1/\$2 a day), and a new objective measure in terms of consumption deprivation — can be linked with the key policy variables contained in the adjustment programmes. A strategy of investment in infrastructure and in human development, and improving access to credit markets, particularly in rural areas to encourage or 'crowd in' private investment is a precondition for growth and poverty alleviation. Debt relief can only provide a temporary, not a sustainable, solution to the problem of reducing poverty.
\end{abstract}

KEY WORDS: Stabilisation; growth; poverty reduction; debt sustainability

\section{Introduction}

This paper develops a model of growth-oriented adjustment and poverty-reduction in developing countries within the policy framework of the Fund-Bank adjustment programmes. The starting point in this paper is the insight that if the new explicit focus of the IMF's concessional lending, as introduced in September 1999 , is poverty reduction, then the IMF model is 'badly designed'. ${ }^{1}$ Thus the model in this paper takes the framework of the Fund and the Bank as the benchmark policy setting, and then shows how demand growth can be a crucial mechanism in determining the potential rate of growth, and demonstrates how poverty-conceptualised officially in absolute terms with a subjective cut-off point (e.g. US $\$ 1 / \$ 2$ a day) and a new objective measure in terms of consumption deprivation-can be linked with the key policy variables contained in such adjustment programmes. Given the declared goal of the IMF's Poverty Reduction Strategy 
Paper (PRSP) as implemented in the Poverty Reduction and Growth Facility (PRGF) and Heavily Indebted Poor Countries (HIPC) programmes, there is a need to develop a model that integrates this policy objective within the Fund-Bank analytical framework.

Khan \& Knight (1981) formulated a structural version of the monetary model with endogenous inflation, balance of payments (BOP) and output; they found fluctuations in money supply playing an important role in explaining inflation movements, but not real output variations. At the same time, growth has been negatively associated with inflation and large budget deficits (Fischer, 1993; Easterly \& Rebelo, 1993). While stabilising the price level has been labelled as 'super-pro-poor' (Dollar \& Kraay, 2002), questions remain about first, whether participation in an IMF or World Bank programme contributes to promoting higher growth in the long run, and second, whether these contributions to growth reduce poverty. Given the gaps in the understanding of the relationship between macroeconomic policies and poverty, such linkages can be assessed by examining alternative policy frameworks and developing a macro-micro model that takes a macroeconomic framework of the Fund-Bank type, and links that to household income and consumption so as to consider consumption poverty, as opposed to income poverty.

Scholarly opinion seems to converge to the conclusion of Przeworski \& Vreeland (2000) that 'if growth is the primary objective then IMF programs are badly designed'. ${ }^{2}$ Using cross-country data, Barro \& Lee (2002) find that an increase in IMF lending has been associated with a reduction of economic growth over the time period 1975-1999. After controlling for endogeneity with instrumental variables for the size of IMF lending, they find no statistically significant impact of IMF lending on economic growth in the contemporaneous 5-year period, but a statistically significant negative effect in the subsequent 5 years. Evrensel (2002) finds that Fund programmes solve BOP problems during programme periods, but are unable to bring about any statistically significant and lasting changes in programme countries' macroeconomic policies. While Taylor (1988) points to inefficient institutional and market structures as reasons for failure of Fund- and Bank-supported programmes, Romer \& Romer (1999) contend that inconsistent macroeconomic policies are among the factors preventing programme countries from encouraging investment and realising growth. Fund-supported stabilisation is generally achieved by lowering investment via a squeeze in domestic liquidity, rather than by increasing savings. Tanzi (1989) finds that because IMF programmes induce governments to save on public investment, this has negative consequences for growth. Investment carries the main burden of reduced absorption-private and public consumption are apparently little influenced by the negotiation of a programme with the Fund - thus has some bearing on the debate over the effects of IMF-backed programmes on the poor (Bird, 2001).

The next critical issue is whether growth benefits the poor. Dollar \& Kraay (2002), using a sample of 80 countries covering 40 years, find that there is a one-toone relationship between income of the bottom fifth of the population and per capita GDP. In other words, average incomes of the poor increase pari passu with overall growth. ${ }^{3}$ Moreover Dollar and Kraay find no evidence that economic crises affect the income of the poor disproportionately. This of course does not mean that an identical proportional decline in income has the same impact on the rich and the poor in terms of economic well-being. Easterly (2000) suggests that government transfers may actually go to the middle-income segment rather than the poor who 
in any case depend more on the informal sector for survival. ${ }^{4}$ The poor lack assets, such as land or other bank collateral-suitable assets, and have little access to credit markets (Easterly, 2000; Agenor, 2002). ${ }^{5}$ Easterly (2000) finds that IMF and WB adjustment lending lowers the growth elasticity of poverty; that is, the proportional change in poverty rates for a given amount of growth. This means that economic expansion benefits the poor less, but at the same time economic contractions hurt the poor less. Moreover, while Easterly found some evidence that adjustment lending has counter-cyclical effects which may smooth the consumption of the poor, there is little evidence that any of the variables-inflation, the black market exchange rate premium, and fiscal transfers-for which adjustment lending altered the cycle, are responsible for smoothing the consumption of the poor. The author is careful to note that this result does not contradict the findings that a relatively low inflation rate $^{6}$ is good for the poor. ${ }^{7}$ Taylor (1983) and others in the literature go as far as arguing that without country-specific structural features, poverty ${ }^{8}$ cannot be incorporated in the IMF-Bank model.

The remainder of this paper is organised in three sections. The next section reviews the Fund-Bank models and points to the limitations of these frameworks, briefly discussing some conceptual and empirical issues. The section following develops an integrated model of poverty reduction within which the possible effects of a Fund-Bank macroeconomic adjustment programme can be analysed. Concluding remarks follow in the final section.

\section{A Review on Fund-Bank Models}

The IMF and the World Bank have relied on their 'financial programming' and 'financing gap' exercises to design a policy framework prioritising macroeconomic stability and growth respectively. Both models, however, have been extensively questioned as long-term policy models. ${ }^{9}$ Khan \& Montiel (1989), and Khan et al. (1990) integrated the two approaches to provide an eclectic policy model known as 'growth-oriented adjustment' programme. A growth-oriented adjustment programme has three objectives: economic growth, BOP improvement and price stability. The task became to determine a set of demand management policies (domestic credit ceilings and reductions in the fiscal deficit), exchange rate, structural policies to increase savings and the level and efficiency of investment, and external financing policies to stabilise inflation and improve the BOP, while maintaining growth.

\section{The IMF Monetary Model}

The Fund's approach to economic stabilisation is known as 'Financial Programming' (FP) that links the monetary sector with the BOP (IMF, 1987). The model of Polak (1957) forms the cornerstone of Fund programmes, attributing BOP disequilibria to excessive credit expansion. ${ }^{10}$ The model comprises the following three relations:

$$
\mathrm{d} M^{s}=e \mathrm{~d} R+\mathrm{d} D C
$$

The first relation is derived from the consolidated balance sheet of the banking system including the Central Bank. It states that the change in assets (ed $R+\mathrm{d} D C){ }^{11}$ i.e. the increase in the stock of international reserves $(\mathrm{d} R)$ of the monetary system 
expressed in domestic currency, plus the increase in domestic credit $(\mathrm{d} D C)$ is eventually equal to the change in liabilities $\left(\mathrm{d} M^{s}\right.$, i.e. the increase in the nominal supply of money). $e$ is the nominal exchange rate expressed as units of domestic currency per unit of foreign currency. Both $M$ and $R$ are endogeneous, while $D C$ is exogeneously fixed by the monetary authorities.

$$
\mathrm{d} M^{d}=\frac{1}{v} \mathrm{~d} Y
$$

The second equation states that the increase in the nominal demand for money $\left(M^{d}\right)$, with $v$ defined as the income velocity $(Y / M)$ and $Y$ the nominal value of output (GDP).

In the simplest version of the model, both $e^{12}$ and $v$ are supposed constant. ${ }^{13}$ Given a target value for the change in reserves (i.e. the overall BOP), and projections for $\mathrm{d} Y$, then the equilibrium expansion in the stock of credit is derived from money market equilibrium $\mathrm{d} M^{d}=\mathrm{d} M^{s}$ as:

$$
\mathrm{d} D \mathrm{C}=\frac{1}{v} \mathrm{~d} Y-e \mathrm{~d} R
$$

In the Polak model, real output (y) is exogenous ('natural rate output' in the classical tradition), while the price level and thus nominal output is endogeneous: $Y=P y$, or, $\mathrm{d} Y=P_{0} \mathrm{~d} y+y_{\mathrm{o}} \mathrm{d} P$, where $P_{0}$ and $y_{0}$ stand for the initial period price level and real income respectively. $P$, which is endogenous, can be expressed as a weighted average of the price of importables $\left(P_{Z}\right)$ and the price of domestic output $\left(P_{D}\right)$, and written as $\mathrm{d} P=\theta \mathrm{d} P_{Z}+(1-\theta) \mathrm{d} P_{D}$ and $\mathrm{d} P_{Z}=P_{Z}^{*} \mathrm{~d} e=\mathrm{d} e$, where $P_{Z}$ is the price of foreign goods measured in foreign currency. It is assumed for convenience that $P_{Z}^{*}=1$. $\theta$ is the share of imports in the price index. Substituting the above relations in (3) and solving the resulting expression for the change in reserves yields:

$$
e \mathrm{~d} R=\frac{1}{v}\left[P_{0} \mathrm{~d} y+\theta y_{0} \mathrm{~d} e+(1-\theta) y_{0} \mathrm{~d} P_{D}\right]-\mathrm{d} D C
$$

This relationship shows the change in reserves from the monetary side, where the desired change in reserves as well as the change in the domestic price level will be influenced by exchange rate and credit policies. ${ }^{14}$ Given two unknowns $(\mathrm{d} R$ and $\left.\mathrm{d} P_{D}\right)$, an additional relationship is needed to determine the values of two endogenous variables. This is obtained from the external sector. The BOP identity is written as

$$
\begin{aligned}
d R & =X-m\left(Y_{0}+d Y\right)+d F, \quad 0<m<1 \\
& =X-m\left(Y_{0}+P_{0} d y+\theta y_{0} d e+(1-\theta) y_{0} d P_{D}\right)+d F
\end{aligned}
$$

where $m$ is the marginal propensity to import, $X$ represents exports, and $\mathrm{d} F$ is the change in net foreign assets excluding monetary reserves. Equations (4) and (5) can be simultaneously solved to obtain the values of the endogenous variables: reserves and inflation. Alternatively, given target values for those two variables, two of the policy instruments ( $\mathrm{d} e$ and $\mathrm{d} D C$ ) can be obtained from the equations (4) and (5), with an exogenous $\mathrm{d} y$, which remains a very restrictive assumption by ignoring the supply side. 


\section{The World Bank Growth Model}

The Bank's concern in its Revised Minimum Standards Model (RMSM), is with medium-term growth and its financing through domestic savings and foreign assistance. Assuming $\sigma$ is the historically or technologically given incremental capital-output ratio (ICOR), the growth of output becomes a linear function of the level of investment. This relationship allows either the growth of real GDP based on the available level of investment to be developed, or the level of investment required for a specified rate of growth. The growth of real output (or in equilibrium, capacity output) is assumed to be a linear function of real investment, treating the increases in factor productivity and the size of the labour force as exogenous. The production function can be represented as

$$
\mathrm{d} y=\alpha_{0}+\alpha_{1} \mathrm{~d} K
$$

$\Rightarrow \mathrm{d} K=I=\frac{1}{\alpha_{1}} \mathrm{~d} y$, and $\mathrm{d} y=\mathrm{d} y *$ where $\frac{1}{\alpha_{1}}=\sigma$, and $\alpha_{1}<1 \Rightarrow \sigma>1$; and $\mathrm{d} y$ denotes the change in real output (GDP), $\mathrm{d} K$ the change in real capital stock or investment $I$, and $\mathrm{d} y^{*}$ the change in potential or capacity output.

The other element in the simple growth model is the identity of aggregate investment and aggregate savings. The aggregate savings behaviour is defined as proportional to real income:

$$
S=s y
$$

where $s$ is the marginal propensity to save with $0<s<1$.

Using the savings-investment identity in an open economy $(S=I+X-Z)$ with constant terms of trade, investment can be written as:

$$
I=s y+(m y-X)
$$

where $\mathrm{Z}$ is imports, which is taken to be a function of income. Combining this relation with $I=\sigma \mathrm{d} y$, and using $y=y_{0}+\mathrm{d} y$, an expression for real GDP growth is obtained as follows:

$$
\mathrm{d} y=\left(\frac{1}{\sigma-s-m}\right)\left[(s+m) y_{0}-X\right]
$$

This relationship implies that the denominator $(\sigma-s-m)$ has to be positive for sustained long-term growth. As shown earlier, $\sigma$ will usually be much greater than one, and $s+m<1$, implying that $\sigma$ can be greater than the sum of the marginal propensities to save and import $(s+m) .{ }^{15}$ This growth equation is very restrictive in the sense that it assumes the complete absence of export-led growth, which will no longer be the case in our expanded model. The core of the Bank approach is to close the saving-investment gap $(S-I=X-Z)$ by linking it to foreign exchange gap $(X-Z=\Delta R-\Delta F$ from equation 5$)$. Thus the relation $S-I=\Delta R-\Delta F$ enables the calculation of the desired level of foreign capital required to finance the targeted growth rate. In this two-gap model, there is no fiscal gap, which will be examined in the following sections. 
Table 1. Structure of the merged framework

\begin{tabular}{lccc}
\hline Endogenous variables & Exogenous and predetermined variables & Policy instruments & Parameters \\
\hline $\mathrm{d} y$ & $\mathrm{~d} F$ & $\mathrm{~d} D C$ & $\alpha_{0}$ and $\alpha_{1}$ \\
$\mathrm{~d} P_{D}$ & $X$ & $\mathrm{~d} e$ & $\sigma, v$ and $\theta$ \\
$\mathrm{d} R$ & $Y_{0}$ and $P_{0}$ & & $s$ and $m$ \\
\hline
\end{tabular}

Source: Abridged version of Khan \& Montiel (1989)

\section{An Analytical Synthesis of the Fund-Bank Model}

In the simple Fund model, real output is determined outside the model, whereas in the Bank model inflation is not determined because the price level is exogenously given and monetary variables play no active role. The merged model-due to Khan et al. (1990) integrating the basic models of the Fund and the Bank-determines growth, inflation and the BOP simultaneously. In equations (4) and (5), dy was exogenous. With an additional relationship for $\mathrm{d} y$ as in equation (9), the values of three endogenous variables (growth, inflation and reserves) can be determined simultaneously. The merged model is solved by condensing it into three relationships between $\mathrm{d} y, \mathrm{~d} P_{D}$ and $\mathrm{d} R$. The key advantage of this merged framework is its simple structure, linking the above macroeconomic targets to government policies and determining the extent of foreign financing gap. The framework is summarised in Table 1.

The results of the merged model are summarised in Table 2. This table shows the signs of the impact effects of changes in the various policy instruments, behavioural parameters and exogenous variables upon prices, real output and the BOP.

The behavioural equations in the merged model are primarily based on ad-hoc rules. Trade and financial liberalisation are included in a policy package for structural adjustment, but they are not explicit in the analytical models. The model also assumes away any role for the public sector in the generation of national output and investment, thus disregarding the fact that public policy to encourage investment-in firms, in labour, in infrastructure-may be important in promoting growth and alleviating poverty (Morrissey \& Filatotchev, 2000). The absence of a detailed fiscal sector does not allow us to examine the impact of government

Table 2. Impact effects of changes in instruments, parameters, and exogenous variables

\begin{tabular}{lccc}
\hline & \multicolumn{3}{c}{ Impact effects on: } \\
\cline { 2 - 4 } Change (increase) in: & Domestic prices $\left(\mathrm{d} P_{D}\right)$ & Real output $(\mathrm{d} y)$ & Balance of payments $(\mathrm{d} R)$ \\
\hline Domestic credit $(\mathrm{d} D C)$ & $>0$ & $>0$ & $<0$ \\
Exchange rate $(\mathrm{d} e)$ & $>0$ & $<0$ & $>0$ \\
Private saving rate $(s)$ & $<0$ & $>0$ & $<0$ \\
ICOR $(\sigma)$ & $>0$ & $>0$ & $>0$ \\
Velocity of money $(v)$ & $>0$ & $>0$ & $>0$ \\
Capital inflows $(\mathrm{d} F)$ & $>0$ & & $>0$ \\
\hline
\end{tabular}

Source: Expanded version of Khan \& Montiel (1989) 
expenditure with its decomposition into government consumption and government investment spending, which will be developed in the next section.

In the Fund-Bank model, monetary policy has a positive impact on output while fiscal and exchange rate policies have a negative impact. Although money growth in excess of output growth drives inflation, the degree of excess capacity in an economy or the gap between actual and potential output will decide the degree of growth of an economy or the 'real pricing power'. Money is the only financial asset in the model. By excluding the interest rate the model leaves out a potentially important channel through which monetary policy could affect the economy. The assumption that DC is exogenously fixed by the monetary authorities is no longer relevant as a monetary policy tool in many countries; instead the interest rate has taken the place of DC as a stabilisation policy instrument. Credit allocation to the private sector, however, does play an important role in stimulating economic activity. In the next section, this issue is addressed by focussing on the role of credit in facilitating economic activity by making a distinction between credit supply to the government and to the private sector. Unlike conventional neoclassical monetary theory, where interest rates alone are assumed to clear the loan market, Stiglitz \& Greenwald (2003) emphasise that credit is quite different from other commodities, as the former is based on information and default risk. Thus a lack of supply of loans to the private sector, particularly to the small or medium-sized firms, can create excess demand for such loans. So for greater economic activity, when there exist negative output gaps in many developing countries, easing the financial constraint at the lower end of the private sector is more important than just the cost of borrowing. The focus of the Fund model on total credit expansion fits well in this context, provided we make a decomposition of credit supply to the government and to the private sector.

\section{An Expanded Model with Poverty Reduction}

Although the merged model reflects the official policies or approaches of the IMF and the World Bank in a growth-oriented adjustment programme, it still cannot address the difficult issues that countries face in putting together a poverty reduction strategy. Thus the design of programs supported by the IMF's PRGF is derived from a country's own poverty reduction strategy. Such a strategy is based upon fully integrated macroeconomic, structural and social policies. ${ }^{16}$ Accordingly, this link is addressed by integrating poverty into a growth-oriented merged model, incorporating a clear distinction between public and private investment and identifying policies that influence private investment so as to accelerate the rate of private capital accumulation and thereby potential output growth.

In formulating the theoretical core of an extended model, the national income identity is written as:

$$
y=C_{p}+C_{g}+I_{p}+I_{g}+I_{f}+X-Z
$$

where $C$ is consumption, and subscripts $p, g$, and $f$ denote private, government and foreign sectors respectively. Here $I_{f}$ refers to foreign direct investment. All variables are measured in real terms.

Private saving $\left(S_{p}\right)$ is assumed to be a function of income net of taxes:

$$
S_{p}=s(y-T)
$$


Fiscal deficits-the difference between total government expenditures $(G=C g+I g)$ and total government revenues $T$-are financed by either money creation $\mathrm{d} D C g$, or net borrowing from abroad $\mathrm{d} F g$, or through a rise in net indebtedness to the domestic private sector $\mathrm{d} B$. Although many developing economies do not have a well-developed domestic government bond market, ${ }^{17}$ we still include $\mathrm{d} B$ as a source of finance and express the budget constraint for the government as:

$$
C_{g}+I_{g}-T=\mathrm{d} D C_{g}+\mathrm{d} F_{g}+\mathrm{d} B
$$

The supply of credit comes from the expansion of the banking system's balance sheet:

$$
\mathrm{d} D C=\mathrm{d} D C_{g}+\mathrm{d} D C_{p}
$$

Substituting (11-13), $Z=m^{*} y^{18}$ and $I_{p}=k^{*} I_{g}{ }^{19}$ into (10) and deriving $\mathrm{d} y$ by using $y=y_{0}+d y$ and substituting out $T$, we obtain:

$$
\begin{gathered}
\mathrm{d} y=\frac{1}{s+m}\left(-(s+m) y_{0}+(1+s) C_{g}+(1+s+k) I_{g}-s \mathrm{~d} D C+s \mathrm{~d} D C_{p}\right. \\
\left.-s \mathrm{~d} F_{g}-s \mathrm{~d} B+I_{f}+X\right)
\end{gathered}
$$

Substituting (4) into (14), the above equation can be written as:

$$
\begin{aligned}
\mathrm{d} y=\frac{1}{s+m}( & -(s+m) y_{0}+(1+s) C_{g}+(1+s+k) I_{g}-\frac{s}{v}\left[P_{0} \mathrm{~d} y+\theta y_{0} \mathrm{~d} e+(1-\theta) y_{0} \mathrm{~d} P_{D}\right] \\
& \left.+s e \mathrm{~d} R+s \mathrm{~d} D C_{p}-s \mathrm{~d} F_{\mathrm{g}}-s \mathrm{~d} B+I_{f}+X\right)
\end{aligned}
$$

Solving for $\mathrm{d} y$, we obtain:

$$
\begin{aligned}
\mathrm{d} y=\frac{v}{v(s+m)+s P_{0}}[ & -(s+m) y_{0}+(1+s) C_{g}+(1+s+k) I_{g}-\frac{s \theta y_{0}}{v} \mathrm{~d} e-\frac{s(1-\theta) y_{0}}{v} \mathrm{~d} P_{D} \\
& \left.+s e \mathrm{~d} R+s \mathrm{~d} D C_{p}-s \mathrm{~d} F_{\mathrm{g}}-s \mathrm{~d} B+\left(I_{f}+X\right)\right]
\end{aligned}
$$

Equation (16) provides a formulation of demand-side influencing output growth, including policies towards investment, with $\mathrm{d} P_{D}$ and $\mathrm{d} R$ as endogenous variables. Although exports $(X)$ and foreign direct investment $\left(I_{f}\right)$ are exogenous variables, they do influence output growth positively. Any increase in $I_{f}$ will stimulate economic activity, whereas increase in foreign borrowing $(\mathrm{d} F g)$ or government debt $(\mathrm{d} B)$ is detrimental to demand growth. Provision of public infrastructure services as reflected in $I_{g}$ has a positive impact on private investment and thereby aggregate demand growth. Poor complementary public capital can significantly reduce private investment. ${ }^{20}$ Equation (16) also suggests that credit to the private sector has a positive impact on demand growth. ${ }^{21}$ Importantly, the lack of property 
rights or perceptions of risk can constrain access to credit. Basu (2002) argues that since the loan market operates in the presence of uncertainty, two additional factors - credit standard and credit risk-are the most important in determining borrowers' access to the loan market. Indeed there may, at the interest rates prevailing in credit markets, be excess demand for credit from small enterprises to whom the banks are unwilling to lend because of perceptions of risk. Governments could prioritise the financing of the SMEs. Caution, however, should be exercised, as credit allocation in favour of priority sectors such as agriculture has been the traditional instrument for monetary policy to play a redistributive role; but it has the disadvantage of increasing the credit risk perception in the loan market, if the non-performing loan assets start to rise.

A country's potential output growth or productive capacity $\mathrm{d} y^{*}$, however, is determined by supply-side factors, summarised as growth in capital $\mathrm{d} K$, in labour $\mathrm{d} L$ and in total factor productivity TFP. TFP may increase as a result of improvements in production technology. ${ }^{22}$ The endogenous growth approach postulates a positive feedback mechanism, captured by use of an augmented aggregate production function such as:

$$
y^{*}=A K^{\gamma}(H L)^{\delta} \text { and } H=E^{\eta}
$$

where $K$ is the physical capital stock including both private and public fixed capital, $L$ is the raw labour input, $H L$ the average level of human capital indicating skilled labour-which is likely to improve productivity, and $A$ is an index of TFP. $E$ is a measure of the education level, and $\eta$ is the economic return to education. Upon substitution and differentiation, we obtain:

$$
\mathrm{d} y^{*}=\mathrm{d} A+\gamma \mathrm{d} K+\delta \mathrm{d} L+\eta \delta \mathrm{d} E
$$

where $\mathrm{d} A$ is the exogenous TFP growth and $\mathrm{d} E$ is the growth of educational attainment or human capital formation. Endogenous growth as formulated in Romer (1986) assumes increasing returns to scale-which was first recognised by Young (1928), and later a dynamic version by Kaldor (1957) in his technological progress function-would require $\gamma+\delta+\eta \delta>1$. Assuming $\gamma=1-\delta \Rightarrow 1+\eta \delta>1$.

The growth of capacity output $\mathrm{d} y^{*}$ as formulated above in the neoclassical framework does not take into account the rate of capacity utilisation or demand growth $\mathrm{d} y$. The change in the rate of capacity utilisation $\mathrm{d} u$ can be written as:

$$
\mathrm{d} u=\mathrm{d} y-\mathrm{d} y *
$$

In order to incorporate this as an error-correction feedback mechanism-where demand growth, being influenced by policies, drives capital accumulation and thus potential output growth-there is a need to formulate a capital accumulation relation in which the net investment can raise the stock of capital as follows:

$$
K_{t}=(1-\rho) K_{t-1}+I_{t} \Rightarrow \mathrm{d} K_{t}=I_{t}-\rho K_{t-1}
$$

where $\rho$ is the rate of depreciation of capital stock and $I=\mathrm{d} K=I_{p}+I_{g}$. Together with the updated values of total factor productivity, a higher capital stock can raise the next period's level of potential output and its growth in the subsequent periods. 
Since demand conditions affect investment spending, and the rate of output growth, ${ }^{23}$ the investment function can be thought of as a relationship transforming desired gross additions to capacity output into the capital accumulation process. Given exogenous public investment, to stimulate growth, private investment spending needs to be determined via the following relation:

$$
I_{p}=\omega_{0}+\omega_{1} \mathrm{~d} u+\omega_{2} p
$$

where the intercept $\omega_{0}$ reflects the state of business confidence and $p$ is the expected rate of profit/return on new investment (or market capitalisation as percentage of GDP). Policy interventions can affect the growth process by directly impacting public investment spending as in equation (16) and consequently influencing private demand conditions as in this formulation via the extent of the output gap or capacity utilisation. Taylor (1994) developed a gap model incorporating both demand and supply sides, along with a discussion of IMF-style financial programming, but the model did not specifically explore how to integrate poverty in such a macroeconomic model.

Assuming that higher growth leads to a decline in poverty, the relation between real GDP growth and change in poverty $\mathrm{d} P V$ can be written as:

$$
\mathrm{d} P V=-\beta_{1} \mathrm{~d} y=-\beta_{1}(\mathrm{~d} Y-\mathrm{d} P)=-\beta_{1}\left(\mathrm{~d} Y-\theta \mathrm{d} e-(1-\theta) \mathrm{d} P_{D}\right)
$$

where $P V$ stands for the poverty ratio or head-count ratio $(H R)$ defined as the proportion of individuals or households earning less than a given absolute level of real income-the poverty line. Poverty is measured by consumption, hence the term poverty line, which is an amount of income needed to purchase a certain amount of goods. ${ }^{24}$

To link poverty reduction with output growth, equation (16) for $\mathrm{d} y$ can be substituted into (17) to get the dynamic relation for the poverty rate with macroeconomic policies:

$$
\mathrm{d} P V=-\beta_{1}\left\{\frac{v}{v(s+m)+s P_{0}}\left[\begin{array}{l}
-(s+m) y_{0}+(1+s) C_{g}+(1+s+k) I_{g}-\frac{s \theta y_{0}}{v} \mathrm{~d} e- \\
\frac{s(1-\theta) y_{0}}{v} \mathrm{~d} P_{D}+s e \mathrm{~d} R+s \mathrm{~d} D C_{p}-s \mathrm{~d} F_{g}-s \mathrm{~d} B+\left(I_{f}+X\right)
\end{array}\right]\right\}
$$

Alternatively, to answer the concerns in the literature about the notion of poverty ${ }^{25}$ and its measures ${ }^{26}$, we follow Kumar et al. (1996) in opting for a measure of poverty grouping people according to their consumer behaviour. ${ }^{27}$ From the observed behaviour, an objective measure of consumption deprivation can be defined. Deprivation can be measured in terms of nutritional or consumption norms. ${ }^{28}$ Kumar et al. use the consumption expenditure on food-grains and derive a nonlinear consumption function of the form:

$$
C=\frac{V_{1} y}{K_{1}+y}
$$

where $C$ is the consumption expenditure on food-grains and $y$ is the total expenditure (a proxy for income that is not observed). This is the equation for a rectangular 
hyperbola with $V_{1}$ and $K_{1}$ as its parameters, where $V_{1}$ represents the saturation level of food-grain consumption expenditure and $K_{1}$ is interpreted as the level of income needed to consume one half of the saturation level. In other words, $V_{1}$ and $K_{1}$ are parameters of a concave Engel curve. Consumption deprivation $(C D)$ or poverty can be defined as the shortfall of actual consumption expenditure relative to saturation level $V_{1}$, or $C D=V_{1}-C$. So from the above non-linear equation we derive the $C D$ function:

$$
C D=\frac{V_{1} K_{1}}{K_{1}+y}
$$

This function, being a convex decreasing function of income, provides a direct measure of poverty based on nutritional norms. Differentiating this function with respect to $y$, we get:

$$
\mathrm{d} C D=-\frac{V_{1} K_{1}}{\left(K_{1}+y\right)^{2}} \mathrm{~d} y
$$

Equation (19) provides a direct link between change in income and consumption deprivation or poverty without any reference to a subjective poverty line. When $C$ approaches its saturation level $V_{1}$, at that point there will be no deprivation or poverty. People who are deprived of that saturation level of food-grains consumption will be considered to be in poverty.

Equation (16) for $\mathrm{d} y$ can be substituted into (19) to reflect the impact of macroeconomic policies on consumption deprivation. Growth in $y$, ceteris paribus, or with no change in income distribution, reduces poverty measured as consumption deprivation, in this case, for food-grains. The food-grain consumption deprivation index can be employed as a poverty index for this homogeneous group.

Extending this approach to the entire economy means assessing the impact of programmes targeted for poverty alleviation, both direct and indirect, using total household consumption expenditures collected through household surveys for different income groups. Homogeneity of consumption bundles is feasible in case of each income group. For different income groups, there would be a different saturation level of consumption, from which the deprivation or shortfall of consumption below the saturation or bliss or critical level can be derived for each income group. Once we have obtained the food-grain deprivation function, the next step would be to aggregate these deprivation values across income groups to devise a poverty index. This type of index is different from the conventional poverty indices in the sense that (1) the CD index does not depend on an arbitrarily chosen poverty line, (2) it depends on the observed and measurable consumption behaviour of people, (3) the index satisfies the standard axioms of a poverty index.

Given that consumption depends on income and the price level, the relationship between the IMF-World Bank policy instruments and poverty could be examined through the impact of the programmes upon consumption deprivation via the general price level and the distribution of income. Assuming that the income distribution can be characterised by a two-parameter function, such as a log-normal distribution, the effect of these programmes on poverty can be examined via the mean and variance of income distribution. The mean and variance of income can be regressed simultaneously on the Fund-Bank policy instruments 
ex-post to examine whether the policies simultaneously increase mean income and reduce income variance, or whether there is a trade-off in that they increase average income but also the variance. Thus $\mathrm{d} y$ can be substituted to reflect changes in policies in the above formulation either as a measure of aggregate demand growth or as changes in distribution of income via changes in mean and variance of the distribution in order to assess their impact on poverty reduction. ${ }^{29}$ As mean income of the income distribution increases, people below a fixed cutoff point will be reduced. Also there could be a trade-off between mean income and deprivation with reduced variance, but if the variance shifts upward, then we can no longer achieve the ideal situation. In order to have a quantitative measure of welfare gains of income growth in terms of reduction in consumption deprivation, the policy maker could use a fixed target of a particular percentage reduction in poverty or consumption deprivation, given an initial level of deprivation. First, there is a need to examine quantitatively the possible impact of policy changes on mean income of different income groups, and second, the possible impact of such changes in mean income on consumption deprivation as a measure of poverty.

\section{Can Debt Relief Help Poverty Reduction?}

New programmes initiated by the IMF and the World Bank include the HIPC Initiative, which, together with the IMF's PRGF provide a focus on social spending and poverty alleviation. ${ }^{30}$ The enhanced HIPC initiative has been designed to provide debt relief to qualifying countries, including partial forgiveness of IMF and World Bank debts. Debt relief, however, does not automatically bring debt sustainability. The government budget constraint, as discussed earlier, can help verify the impact of external debt on growth and thereby poverty. The empirical literature to establish a relationship between government foreign debt and the growth rate of per capita GDP have reported mixed evidence. Lin \& Sosin (2001) find that foreign debt and growth of per capita GDP are negatively related at high level of significance for African countries. The relationship is also negative for industrialised and Latin American countries. It is, however, positive for Asian and other developing countries, although statistically insignificant.

Equation (16) suggests a negative relationship between growth of external debt $\mathrm{d} F_{g}$ and real GDP growth. This implies that reducing debt obligations may help growth by keeping the debt dynamics stable. Rewriting equation (16) expressing $\mathrm{d} f_{g}\left(\mathrm{~d} F_{g}\right.$ net of changes in reserves) in terms of $\mathrm{d} y$ gives:

$$
\begin{aligned}
\mathrm{d} f_{g}= & -\frac{v(s+m)+s P_{0}}{s v} \mathrm{~d} y-\frac{(s+m) y_{0}}{s}+\frac{(1+s)}{s} C_{g}+\frac{(1+s+k)}{s} I_{g} \\
& -\frac{\theta y_{0}}{v} \mathrm{~d} e-\frac{(1-\theta) y_{0}}{v} \mathrm{~d} P_{D}+\mathrm{d} D C_{p}-\mathrm{d} B+\frac{1}{s}\left(I_{f}+X\right)
\end{aligned}
$$

Equation (20) suggests that a steady increase in $\mathrm{d} y$ will keep debt dynamics under control. Given a negative relation between $\mathrm{d} f g$ and $\mathrm{d} y$, a sudden contraction in output growth will intensify pressure from debt service obligations. This reinforces or reformulates traditional arguments for fiscal prudence for debt sustainability. Growing public debt will eventually mean higher taxes for the debt to be serviced. Governments may be tempted to seek an escape route through increased 
seigniorage revenue (indicated by the negative sign for $\mathrm{d} P_{D}$ ) in order to keep the debt dynamics stable, but the resulting inflation may eventually lead to either equivalent currency depreciation or an increase in domestic nominal interest rates $i$ in order to stem the expected capital outflows. Assuming imperfect capital mobility, and adding a risk premium $\varphi$ to the uncovered interest parity (UIP) condition, we obtain:

$$
\mathrm{d} e=\left(i^{*}-i\right)-\phi\left(\frac{f_{g}}{X}\right)
$$

where $i^{*}$ is world interest rate and $\varphi$ is assumed to be a positive function of the external debt $\left(f_{g}\right)$-exports ratio. It is export earnings that ultimately determine the capacity to repay external obligations. Including this UIP and $i=r+\mathrm{d} p_{D}$, equation (17) can be rewritten as follows:

$$
\begin{array}{r}
\mathrm{d} f_{g}=-\frac{v(s+m)+s P_{0}}{s v} \mathrm{~d} y-\frac{(s+m) y_{0}}{s}+\frac{(1+s)}{s} C_{g}+\frac{(1+s+k)}{s} I_{g}-\frac{\theta y_{0}}{v} \\
\left\{i^{*}-\left(r+\mathrm{d} p_{D}\right)-\phi\left(\frac{f_{g}}{X}\right)\right\}-\frac{(1-\theta) y_{0}}{v} \mathrm{~d} P_{D}+\mathrm{d} D C_{p}-\mathrm{d} B+\frac{1}{s}\left(I_{f}+X\right)
\end{array}
$$

Rearranging the variables, the evolution of external debt can be expressed as the difference between real interest rate and real growth rate, along with other variables as follows:

$$
\begin{aligned}
\mathrm{d} f_{g}=[ & \left.\frac{\theta y_{0}}{v} r-\frac{v(s+m)+s P_{0}}{s v} \mathrm{~d} y\right]+\frac{(2 \theta-1) y_{0}}{v} \mathrm{~d} P_{D}-\frac{\theta y_{0}}{v} i *+\frac{\theta y_{0}}{v} \phi\left(\frac{f_{g}}{X}\right) \\
& +\frac{(1+s)}{s} C_{g}+\frac{(1+s+k)}{s} I_{g}+\mathrm{d} D C_{p}-\mathrm{d} B+\frac{1}{s}\left(I_{f}+X\right)-\frac{(s+m) y_{0}}{s}
\end{aligned}
$$

This debt dynamics equation also suggests that there is a trade-off between domestic and external debt by the government, and as export earnings decline, the debt dynamics appears explosive. Debt forgiveness can give some fiscal space for the HIPCs, but removing the debt overhang does not mean that a country will not fall back into unsustainable levels of debt (Granville, 2003). Even after two decades of debt relief efforts, the HIPCs still remain heavily indebted, and average policies in HIPCs 1980-1997 were worse than other LDCs (Easterly, 2002b). For the success of current debt relief efforts, only the growth of exports, income and fiscal revenue can guarantee a sustainable debt level. The key to preventing a debt crisis is to monitor closely the sustainability of debt dynamics, with alternative assumptions on real growth rate and the real interest rate. As long as the real growth rate exceeds the real interest rate, the existing debt can in principle be serviced by the sale of new debt. If not, this should give the first signal to the sovereign to get its fiscal house in order so as to help prevent a financial crisis. In a situation where there is no problem on the fiscal side, there could still be default risk if there is currency overvaluation. Thus the ex-ante policy action is the key to maintaining macroeconomic stability with growth. 


\section{Conclusion}

This paper reviews the Fund-Bank analytical frameworks and then integrates poverty reduction into the policy framework. Within the framework, the demand and the supply sides are integrated linking macroeconomic policies to targets. It provides an explicit treatment of the demand side in addition to the standard supply-driven neoclassical framework. The impact of macroeconomic policies on poverty reduction can be addressed directly via the mean and variance of income distribution along with aggregate GDP. The impact of external debt on growth and thereby poverty is also verified. Debt relief is found to provide a temporary, not a sustainable, solution to the problem of reducing poverty, thereby making the ex-ante policy actions as the key to growth-oriented adjustment.

The paper suggests targeting public investment spending growth to overcome infrastructural deficiencies (that hold back private production and investment) for higher output growth, while reducing government consumption spending or minimising the size of government operations could help achieve fiscal stability. Government's infrastructure, public utility, and even manufacturing projects are likely to 'crowd in' investment by the private sector by making it more profitable, instead of crowding it out through the mechanism of higher government borrowing putting pressure on financial markets (Taylor, 1993). Taylor (1988) argued that public and private investments are complementary. Given the complementarity of public and private sector investment, particularly with regard to public investment in infrastructure, Agenor (2002) emphasises that a cut in public investment expenditures may reduce the productivity of the private capital stock at the margin, and thus reduce private expenditure and aggregate demand. During fiscal contractions, government capital spending seems indeed to be reduced more than other categories of spending. For instance, in India, following the stabilisation programme in 1991, a sizable portion of the adjustment came from a reduction in government capital expenditure including cutback in agricultural capital formation, while the growth in government current expenditures (such as wages and operational expenses, interest payments, and defence spending) remained unaffected. ${ }^{31}$ Such a decline in public capital spending particularly in public infrastructure could have growth retarding effects. ${ }^{32}$ In turn, infrastructural bottlenecks and lack of access to credit markets just exacerbate the fact that the poor may find themselves isolated from the formal sector of the economy. ${ }^{33}$

\section{Acknowledgements}

This is a revised version of the paper presented at the UK Development Studies Association Annual Conference, organised by the Department of Economics, Strathclyde University, Glasgow, 10-12 September 2003. Thanks are due to Ayse Evrensel, T. Krishna Kumar, S. Mansoob Murshed, Peter Oppenheimer and Eric Pentecost for their helpful comments on an earlier version of this paper. We are also grateful to two anonymous referees of this journal and the editor, Malcolm Sawyer, for their useful comments. The usual disclaimer applies.

\section{Notes}

1. See Easterly (2000, p. 1). Easterly also quotes the IMF web-site which says: 'In September 1999, the objectives of the IMF's concessional lending were broadened to include an explicit focus on poverty reduction in the context of a growth oriented strategy. The IMF will support, along with the World 
Bank, strategies elaborated by the borrowing country in a Poverty Reduction Strategy Paper (PRSP).' http://www.imf.org/external/np/exr/facts/prgf.htm. See also www.imf.org for a factsheet on Poverty Reduction Strategy Papers.

2. Przeworski \& Vreeland (2000, p. 403). On p. 386 the authors review some of the literature on whether the IMF programmes have positive effects on growth.

3. Dagdeviren et al. (2002) find that redistribution, either of current income or of the growth increment of income, is more effective in reducing poverty for a majority of countries than growth alone.

4. See Easterly (2000): the author takes the example of Zambia and Burkina Faso where he shows that 'self-unemployment is extremely important for the poorest deciles in Zambia. The bias is less extreme in Burkina Faso, but the poorest still have their earnings skewed towards self-employment income. These surveys are suggestive of the importance of the informal sector for the poorest households, lending credence to the relative insulation of the poor from structural adjustment measures.'

5. Das \& Mohapatra (2003) find no evidence of any statistical association between financial liberalisation and lowest income quintile's share of mean income.

6. Pooling information from 87 countries for the years 1970-1990, Sarel (1996) discovered a structural break in the relationship between rates of economic growth and inflation. The break is estimated to occur when the annual inflation rate is $8 \%$. Between 0 and $8 \%$, Sarel found that the inflation rate either has no effect or even has a slight positive effect on economic growth. Once inflation rises above $8 \%$ per annum, a significant negative effect on growth rates emerges. Easterly et al. (1995) found the costs more seriously and lastingly damaging when inflation is above $40 \%$ a year. Whether inflation is a result of wage-push or demand pressures requires investigation before examining its effects. Historically, high inflation in developing countries has been mainly the result of either excess money creation to finance fiscal deficits or currency devaluation to finance external deficits (for the case of India, see Mallick, 2004). For the sake of simplicity, in this paper, we focus on the overall domestic inflation without distinguishing its sources.

7. Blank \& Blinder (1986) found that inflation increases poverty rates, but also slightly increases the income shares of the bottom two quintiles. On balance they found little evidence that inflation hits the poor harder than the rich. Cardoso (1992) found that in Latin America the inflation tax does not affect those already below the poverty line, because they hold little cash. Cardoso also found that higher inflation is associated with lower real wages. In Granville et al. (1996), high inflation in early transition Russia seems to increase poverty through the inflation tax on cash and also wages and pensions, since they were not systematically indexed to inflation. Agenor (1999) finds that inflation always increases the poverty rate, using a cross-section of 38 countries. Easterly \& Fischer (2000) found that the poor tend to rate inflation as a top concern, using survey data on 31,869 households in 38 countries. Using data for Indian states, Ravallion \& Datt (2002) find some evidence that inflation is significant in explaining poverty.

8. See Addison et al. (2002).

9. See Edwards (1989) and for a survey of the controversial analytical issues in the design of IMF programmes, see Killick (1995, ch. 4).

10. See Polak (1998) for a comprehensive description of the FP framework and IMF $(1977,1987)$.

11. Here the symbol $\mathrm{d}$ is used to denote the change in a variable from the last period $\left(y_{0}\right)$ to the present (y); that is, $\mathrm{d} y=\Delta y=y-y_{0}$ and so on.

12. Recently, emerging market economies such as Brazil, when faced with credibility problems, have abandoned their fixed exchange rate (currency board) arrangements and have moved to a flexible system (in some countries with implicit inflation targets). The question remains as to how to adapt the traditional quantitative monetary conditionality (a ceiling on domestic credit) to the specific features of monetary policy under inflation targeting. When inflation is the overriding objective, having a credit ceiling may be considered somewhat superfluous, or at least, a non-binding constraint (see Blejer et al., 2002).

13. Easterly (2002a) finds that the assumption of constant velocity fails in the data and velocity is found to be non-stationary.

14. See Polak (1998).

15. There have been several attempts of extending the standard growth models by incorporating dynamics and building more economic structure, but very few of these have been reflected so far in the Bank model (Easterly, 1999).

16. See 'Key features of IMF's PRGF supported programs' at http:/ / www.imf.org/external/np/prgf/ 2000/eng/key.htm

17. By the end of 2001, only 20 emerging economies had outstanding domestic government bonds ranging from a maximum market capitalisation of US $\$ 340$ billion in case of Brazil to a minimum of US \$5 billion in Chile (source: JPMorgan Local Markets Guide, 2002). 
18. A structural export relation can also be incorporated, with exports being a positive function of world output $\left(y_{w}\right)$ and a negative function of the terms of trade $\left(p_{x} / p_{m}\right)$.

19. We assume that private investment and public investment on infrastructure are complements, with private-investment being bounded above by the level of public-investment, with $k$ as the ratio of private to public capital in the composite capital stock. Actual output will rise, through Keynesian demand effects via higher levels of both private and public investment, thereby bringing the economy closer to full capacity utilisation.

20. Reinikka \& Svensson (2002) find that the private investment response to date has been mixed, even among the strongest reformers. This disappointing result can be partly explained by the continued poor provision of public capital and services.

21. Levine (1997) and Levine et al. (2000) have documented a positive long-run relationship between financial development and economic growth. Moreover, Jalilian \& Kirkpatrick (2002) suggest that financial sector development policy can contribute to poverty reduction in developing countries via growth.

22. Young (1995) provides evidence of the role played by factor accumulation in explaining the postwar growth of Hong Kong, Singapore, South Korea, and Taiwan. Young finds that while the growth of output and manufacturing exports in the newly industrialising countries of East Asia is virtually unprecedented, the growth of TFP in these economies is not. In contrast, Chand \& Sen (2002), in the context of Indian manufacturing, find that trade liberalisation has raised TFP growth.

23. See Arestis \& Sawyer (1998) for the role of aggregate demand in setting the level of economic activity, and Setterfield (2002) for a detailed exposition on demand-led growth models.

24. Kumar et al. (1996, p. 55): “The standard approach which goes as far back as Rowntree (1901) is to define a poverty line in terms of a minimum level of income needed to purchase the basic necessities of life and use the income distribution to see what percentage of the people have an income less than such a poverty line. This measure is called Head Count Ratio $(\mathrm{H})$.' $^{\prime}$

25. Kumar et al. (1996, p. 54): 'Poverty connotes the notion of a poor state of economic well-being or a state of economic ill-being. It connotes a state of economic deprivation. Deprivation can be based on comparing an individual's economic state with either an absolute norm, in which case it is called an absolute deprivation, or a normative or relative norm, in which case it is called a relative deprivation.'

26. See Ravallion (1994) for a discussion on measures of poverty.

27. In general, since the income-based method falls short in situations where for some attributes, markets do not exist, Mukherjee (2001) examined analytically the problem of measuring deprivation in an economy with more than one attribute. However, given the importance of nutritional needs for survival, we focus on the deprivation of essential food-grains as a proxy for poverty.

28. Sen (1976) introduced the notion of deprivation in the income distribution literature, but focused on the head-count ratio as a measure of poverty. Rao (1981) suggested broadening the scope of poverty measurement to nutritional norms as opposed to monetary measures. Rao suggested that data on the proportion spent on food (PSF) per capita can be exploited to measure the incidence of deprivation and poverty; and until the food needs are satisfied, people spend relatively more of their incremental income on food and this behaviour reveals itself as increasing or invariant PSF, as income (or expenditure) increases up to a critical level. In other words, the proportion of people up to that critical level are deprived of the required food and the proportion constitutes the incidence of deprivation and the average expenditure at the deprivation point can be used to develop a poverty line.

29. Kumar et al. (1996, pp. 68-69): 'The real problem with poverty, is not the mean level of consumption deprivation, but it is the variability of the consumption deprivation. The lower income persons are more susceptible for deprivation as the spread of actual consumption is so wide due to high variance that it can go below the consumption requirements more frequently. Even if the variability is same at different income levels the probability that a person's consumption falls below the minimum required consumption is more for a lower income person than for a higher income person. This is because the mean deprivation is a decreasing function of incomes at all levels of income. It is the variability in the consumption deprivation, and that too the possibility of differential variability at different income levels, that causes a major problem for the poor.'

30. For details on the HIPC initiative, see Abrego \& Ross (2001).

31. See Mallick (1999) for detailed evidence on this issue.

32. See Mallick (2001) for the policy simulations of this effect. For example, in the case of India, compression of government consumption expenditure over the years has been made difficult by the contractual nature of much of current expenditures and rigidities in the expenditure pattern 
(Economic Survey 2001-2002, Government of India: www.finmin.nic.in). Ghatak \& Ghatak (1997) find significant crowding-out effects of government consumption on private consumption.

33. Easterly (2000) notes that the urban informal sector is documented to be very large in most developing countries especially the very poor ones, one can deduce that the rural informal sector is even larger.

\section{References}

Abrego, L. \& Ross, D. C. (2001) Debt relief under the HIPC initiative: context and outlook for debt sustainability and resource flow, Discussion Paper No. 2001/96, UNU/WIDER, Helsinki.

Addison, T., Chowdhury, A. R. \& Murshed, S. M. (2002) By how much does conflict reduce financial development? Discussion Paper No. 2002/48, UNU/WIDER, Helsinki.

Agenor, P. R. (1999) Stabilization policies, poverty, and the labor market, in: E. Thorbecke (Ed.) Poverty in Sub-Saharan Africa (Ithaca, NY: Cornell University Press).

Agenor, P. R. (2002) Macroeconomic adjustment and the poor: analytical issues and cross-country evidence, World Bank Working Paper No. 2788, World Bank, Washington, DC.

Arestis, P. \& Sawyer, M. (1998) Keynesian economic policies for the new millennium, The Economic Journal, 108(446), pp. 181-195.

Barro, R. J. \& Lee, J. W. (2002) IMF programs: who is chosen and what are the effects? NBER Working Paper No. w8951, May.

Basu, S. (2002) Financial Liberalization and Intervention: A New Analysis of Credit Rationing (Cheltenham, UK: Edward Elgar).

Bird, G. (2001) IMF programs: do they work? Can they be made to work better?, World Development, 29(11), pp. 1849-1865.

Blank, R. M. \& Blinder, A. S. (1986) Macroeconomics, income distribution, and poverty, in: S.H. Danziger \& D.H. Weinberg (Eds) Fighting Poverty: What Works and What Does Not, pp. 180-208 (Cambridge, MA: Harvard University Press).

Blejer, M. I., Leone, A. M., Rabanal, P. \& Schwartz, G. (2002) Inflation targeting in the context of IMFsupported adjustment programs, IMF Staff Papers, 49(3), pp. 313-338.

Cardoso, E. (1992) Inflation and poverty, National Bureau of Economic Research (NBER), Working Paper No. 4006, March, Cambridge, MA.

Chand, S. \& Sen, K. (2002) Trade liberalization and productivity growth: evidence from Indian manufacturing, Review of Development Economics, 6(1), pp. 120-132.

Dagdeviren, H., van der Hoeven, R. \& Weeks, J. (2002) Poverty reduction with growth and redistribution, Development and Change, 33(3), pp. 383-413.

Das, M. \& Mohapatra, S. (2003) Income inequality: the aftermath of stock market liberalization in emerging markets, Journal of Empirical Finance, 10(1-2), pp. 217-248.

Dollar, D. \& Kraay, A. (2002) Growth is good for the poor, Journal of Economic Growth, 7(3), pp. 195-225.

Easterly, W. (1999) The ghost of financing gap: testing the growth model used in the international financial institutions, Journal of Development Economics, 60, pp. 423-438.

Easterly, W. (2000) The effect of IMF and World Bank programs on poverty, World Bank, 31 October. Available at http:/ / www.imf.org/external/pubs/ft/staffp/2000/00-00/e.pdf

Easterly, W. (2002a) An identity crises? Testing IMF financial programming. Working paper No. 9, August, Center for Global Development, Washington, DC.

Easterly, W. (2002b) How did heavily indebted poor countries become heavily indebted? Reviewing two decades of debt relief, World Development, 30(10), pp. 1677-1696.

Easterly, W. \& Fischer, S. (2000) Inflation and the poor. Working Paper No. 2335, The World Bank, Washington.

Easterly, W. \& Rebelo, S. (1993) Fiscal policy and economic growth: an empirical investigation, Journal of Monetary Economics, 32(3), pp. 417-458.

Easterly, W., Mauro, P. \& Schmidt-Hebbel, K. (1995) Money demand and seigniorage-maximizing inflation, Journal of Money, Credit and Banking, 27(2), pp. 583-603.

Edwards, S. (1989) The international monetary fund and the developing countries: a critical evaluation, in: K. Brunner \& A. Meltzer (Eds), Carnegie-Rochester Conference Series on Public Policy, 31, Fall, pp. 7-68.

Evrensel, A. Y. (2002) Effectiveness of IMF-supported stabilization programs in developing countries, Journal of International Money and Finance, 21(5), pp. 565-587.

Fischer, S. (1993) The role of macroeconomic factors in growth, Journal of Monetary Economics, 32(3), pp. 485-512. 
Ghatak, A. \& Ghatak, S. (1996) Budgetary deficits and Ricardian equivalence: the case of India, 19501986, Journal of Public Economics, 60(2), pp. 267-282.

Granville, B. (2003) Strengthening the link between debt relief and poverty reduction: the HIPC initiative, in: V. Aggarwal \& B. Granville (Eds) Sovereign Debt: Origins, Crises, and Restructurings, pp. 36-57 (London: RIIA).

Granville, B., Shapiro, J. \& Dynnikova, O. (1996) Less inflation, less poverty: first results for Russia, Discussion Paper No. 68, RIIA, London.

International Monetary Fund (1977) The Monetary Approach to the Balance of Payments (Washington, DC: IMF).

International Monetary Fund (1987) Theoretical aspects of the design of fund-supported adjustment programs, Occasional Paper No. 55, Washington, DC, September.

Jalilian, H. \& Kirkpatrick, C. (2002) Financial development and poverty reduction in developing countries, International Journal of Finance \& Economics, 7(2), pp. 97-108.

Kaldor, N. (1957) A model of economic growth, Economic Journal, 67, pp. 591-624.

Khan, M. S. \& Knight, M. D. (1981) Stabilization programs in developing countries: a formal framework, IMF Staff Papers, 28, March, pp. 1-53.

Khan, M. S. \& Montiel, P. J. (1989) Growth-oriented adjustment programs: a conceptual framework, IMF Staff Papers, 36, June, pp. 279-306.

Khan, M. S., Montiel, P. J. \& Haque, N. U. (1990) Adjustment with growth: relating the analytical approaches of the IMF and the World Bank, Journal of Development Economics, 32, pp. 155-179.

Killick, T. (1995) IMF Programmes in Developing Countries: Design and Impact (London: Routledge).

Kumar, T. K., Gore, A. P. \& Sitaramam, V. (1996) Some conceptual and statistical issues on measurement of poverty, Journal of Statistical Planning and Inference, 49, pp. 53-71.

Levine, R. (1997) Financial development and economic growth: views and agenda, Journal of Economic Literature, 35(2), pp. 688-726.

Levine, R., Loayza, N. \& Beck, T. (2000) Financial intermediation and growth: causality and causes, Journal of Monetary Economics, 46(1), pp. 31-77.

Mallick, S. K. (1999) Modelling Macroeconomic Adjustment with Growth in Developing Economies: The Case of India (Aldershot, UK: Ashgate).

Mallick, S. K. (2001) Dynamics of macroeconomic adjustment with growth: some simulation results, International Economic Journal, 15(1), pp. 115-139.

Mallick, S. K. (2004) A dynamic macroeconometric model for short-run stabilization in India, Applied Economics, 36(3), pp. 261-276.

Morrissey, O. \& Filatotchev, I. (2000) Globalisation and trade: the implications for exports from marginalised economies, Journal of Development Studies, 37(2), pp. 1-12.

Mukherjee, D. (2001) Measuring multidimensional deprivation, Mathematical Social Sciences, 42(3), pp. 233-251.

Polak, J. J. (1957) Monetary analysis of income formation and payments problems, IMF Staff Papers, 5, $1-50$.

Polak, J. J. (1998) The IMF monetary model at 40, Economic Modelling, 15(3), pp. 395-410.

Przeworski, A. \& J. R. Vreeland (2000) The effect of IMF programs on economic growth, Journal of Development Economics, 62, pp. 385-421

Rao, V. V. B. (1981) Measurement of deprivation and poverty based on the proportion spent on food: an exploratory exercise, World Development, 9(4), pp. 337-353.

Ravallion, M. (1994) Poverty Comparisons (Chur, Switzerland: Harwood Press).

Ravallion, M. \& Datt, G. (2002) Why has economic growth been more pro-poor in some states of India than others?, Journal of Development Economics, 68(2), pp. 381-400.

Reinikka, R. \& Svensson, J. (2002) Coping with poor public capital, Journal of Development Economics, 69(1), pp. 51-69.

Romer, C. \& Romer, D. (1999) Monetary policy and the well-being of the poor, Economic Review, Federal Reserve Bank of Kansas City, First Quarter, pp. 21-49.

Romer, P. (1986) Increasing returns and long-run growth, Journal of Political Economy, 94, pp. 1002-1037. Rowntree, B. S. (1901) Poverty: A Study of Town Life (London: Macmillan).

Sarel, M. (1996) Non-linear effects of inflation on economic growth, IMF Staff Papers, 43(1), pp. $199-215$.

Sen, A. K. (1976) Poverty: an ordinal approach to measurement, Econometrica, 44, pp. 219-231.

Setterfield, M. (Ed.) (2002) The Economics of Demand-Led Growth: Challenging the Supply-Side Vision of the Long Run (Cheltenham, UK: Edward Elgar).

Stiglitz, J. E. \& Greenwald, B. (2003) Towards a New Paradigm in Monetary Economics (Raffaele Mattioli Lectures) (Cambridge: Cambridge University Press). 
Tanzi, V. (1989) Fiscal policy, stabilization and growth, in: M. I. Blejer \& K.-Y. Chu (Eds) Fiscal Policy Stabilization and Growth in Developing Countries (Washington, DC: IMF).

Taylor, L. (1983) Structuralist Macroeconomics (New York: Basic Books).

Taylor, L. (1988) Varieties of Stabilization Experience: Towards Sensible Macroeconomics in the Third World, WIDER studies in Development Economics (Oxford: Clarendon Press).

Taylor, L. (1993) A three-gap analysis of foreign resource flows and developing country growth, in: L. Taylor (Ed.) The Rocky Road to Reform: Adjustment, Income Distribution, and Growth in the Developing World (Cambridge, MA: MIT Press).

Taylor, L. (1994) Gap models, Journal of Development Economics, 45(1), pp. 17-34.

Young, A. (1995) The tyranny of numbers: confronting the statistical realities of the East Asian growth experience, Quarterly Journal of Economics, 110(3), pp. 641-680.

Young, A.A. (1928) Increasing returns and economic progress, Economic Journal, 38, pp. 527-542. 